\title{
Evaluation of Coping Strategies of Male Patients, Being Treated in Internet Addiction Outpatient Clinic in Turkey
}

\author{
Omer Senormanci ${ }^{1}$, Ramazan Konkan², Oya Guclu², Guliz Senormanci
}

\section{ÖZET:}

Türkiye'deki internet bag̃ımlılıg̃ı poliklinig̃inde tedavi edilen erkek hastalarda, başa çıkma tutumlarının deg̃erlendirilmesi

Amaç: Bu çalıșmanın amacı erkek internet bag̃ımlılarının başa çıkma tutumlarının sag̃lıklı gönüllülerdekilerle karşılaştırılmasıdıdr.

Yöntem: İnternet bag̃ımlılı̃̃ı poliklinig̃imize bașvuran, klinik olarak internet bag̃ımlıı̃̃ tanısı alan elli erkek hasta ve benzer sosyodemografik özelliklere sahip internet bag̃ımlılı̃ı olmayan elli sag̃lıklı erkek çalıșmaya alınmıştır. Hastalar sosyodemografik ve klinik veri formu, innternet Bag̃ımlıı̃̃ı Testi (BBT), Beck Depresyon Envanteri (BDE) Başa Çıkma Tutumlarını Deg̃erlendirme ölçeg̃i (COPE) ile deg̃erlendirilmiştir.

Bulgular: Hasta grubunun günlük internet kullanım süresi, IBT puanları ve BDE puanları kontrol grubuna göre istatistiksel olarak anlamlı yüksek bulunmuştur $(p<0.001)$. Kontrol grubunda sorun odakı başa çıkma tutumlarından yararlı sosyal destek kullanımı ( $p<0.05)$, aktif başa çıkma, plan yapma $(p<0.001)$, duygusal odaklı bașa çıkma tutumlarından pozitif yeniden yorumlama ve gelișme, dini olarak bașa çıkma $(p<0.001)$, duygusal sosyal destek kullanımı, soruna odaklanma ve duyguları açı̃a vurma $(p<0.05)$ strateji puanları anlamlı düzeyde yüksek iken, şakaya vurma, ișlevsel olmayan bașa çıma tutumlarından zihinsel boș verme, inkâr, davranışsal olarak boș verme, alkol-madde kullanımı kontrol grubunda istatistiksel olarak anlamIı düzeyde düșük bulunmuștur ( $p>0.05)$. Depresyonun karıştıııcı etkisi kontrol altına alındıg̃ında şakaya vurma, zihinsel boș verme, inkâr, alkol-madde kullanımı, toplam işlevsel olmayan baș etme tutumları puanlarında anlamlı düzeyde farkı bulunmamıştır ( $p>0.05)$. Ancak kontrol grubunda kabullenme istatistiksel olarak anlamlı yüksek bulunmuştur $(p<0.05)$.

Sonuç: İnternet bag̃ımlılig̃ı olan hastalarda başa çıkma tutumlarında bazı farklılıklar bulunmaktadır. Çalıșmamız baș etme tutumlarının araștıııldıg̃ı hasta grubu üzerinde yapılan ilk çalıșmalardan biridir. Baș etme tutumlarının göz önünde bulundurulması internet bag̃ımlıIı̃ı olan hastaların deg̃erlendirilmesine yararlı olabilir.

Anahtar sözcükler: internet bag̃ımlıİg̃ı, baș etme tutumları

Journal of Mood Disorders 2014;4(1):14-9

\section{ABSTRACT:}

Evaluation of coping strategies of male patients, being treated in internet addiction outpatient clinic in Turkey

objective: The purpose of this study is to compare the coping strategies of male internet addicts with a healthy control group.

Methods: Fifty male patients presented to our internet addiction outpatient clinic who were clinically diagnosed as internet addict and 50 healthy male without internet addiction who had similar sociodemographic characteristics have been included in the study. The patients were assessed by sociodemographical and clinical interview form, the Internet Addiction Test (IAT), the Beck Depression Inventory (BDI), and the Coping Inventory (COPE).

Results: The mean daily duration of internet use, IAT scores, and BDI scores in the study group were significantly higher than those of the control group $(p<0.001)$. The scores of coping strategies as problem focused, using instrumental social support $(p<0.05)$, active coping, planning $(p<0.001)$, emotional focused, positive reinterpretation and growth, turning to religion $(p<0.001)$, use of emotional social support, focusing on and venting of emotions $(p<0.05)$ were significantly higher, while the scores of humour, dysfunctional, mental disengagement, denial, behavioral disengagement, alcohol-drug disengagement were significantly lower in the control group $(p>0.05)$. After controlling the confounding effect of depression; the mean scores of coping strategies as humour, mental disengagement, denial, alcohol-drug disengagement, and total dysfunctional were not significantly different between the groups anymore ( $p>0.05)$, but mean acceptance score in the control group became significantly higher $(p<0.05)$. Conclusions: There are some differences among patients with internet addiction in terms of coping strategies. Our study is one of the first studies that have investigated coping strategies among patients with internet addiction. Considering coping strategies may be helpful when evaluating patients with internet addiction.

Key words: internet addiction, coping strategies

Journal of Mood Disorders 2014;4(1):14-9

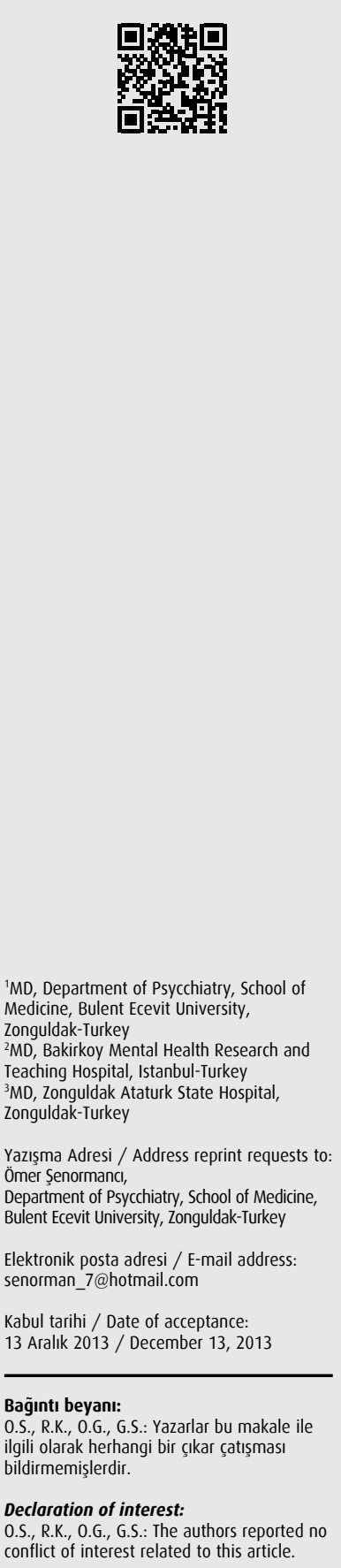




\section{INTRODUCTION}

The internet that was developed to increase communication and facilitate information exchange has grown beyond expectations, but also some users unable to control their internet use and thus experience significant impairments at their work, and in their social and private lives. Internet overuse has been defined as excessive cognitive involvement associated with the use of the internet, unsuccessful attempts to limit and control the use, inability to cease craving for access, persistence in using the internet in spite of impaired functioning at various levels, spending gradually increasing much more time in the internet and longing and craving when there is no possibility of using it (1).

In the literature, various terms are used for overuse or uncontrolled use of internet. 'Internet addiction' which is also used in our article, is the most popular term used for this disorder that should be considered among nonsubstance behavioral addictions in DSM-IV system (2). Recently, the disorder was included in DSM-5. Internet overuse matter took part in section 3 as internet use gaming disorder that is more research need to be done in order to be a formal disorder (3).

People having functional loss develop several coping mechanisms in order to minimize or totally recover from the negative consequences of the disease within their cultural and personal principals (4).

Several researchers classified coping strategies in different ways. Lazarus (1993) suggests that coping is performed in two ways as emotion-focused and problemfocused. Problem-focused coping mechanisms are more adaptational, protective and improving for individuals, whereas, emotion-focused coping mechanisms are more likely to impair adaptation, inhibit improvement and are more defensive (5). While problem-focused coping strategies aim to solve the problem or trying to change the source of stress (e.g. planning), emotion-focused coping strategies aim to reduce the sensation of distress or to manage the stress (e.g. denial). It has been known that dysfunctional coping strategies play a role in the relationship between the stress factors or daily life events and psychiatric disorders (6).

In a study that has used the Ways of Coping Scale (WOC), men with problematic internet use were more likely to engage in 'social support seeking', whereas women were more likely to try to 'keep to themselves' or engage in 'wishful thinking' (both avoidant coping strategies). For men, increased 'wishful thinking' was associated with increased internet addiction. It is likely that 'wishful thinking' may allow men who engage in internet addiction to approach the Internet repeatedly as an attempt to meet some need, regardless of the success of the approach (7).

The purpose of this study was to evaluate the coping strategies in patients with internet addiction. Detecting the coping strategies used by the individuals may be helpful in establishing their role in emergence and persistence of internet addiction, in determining treatment goals and observing therapeutic efficacy. In our study, coping strategies that are considered to play role in psychiatric disorders were investigated among patients with internet addiction.

\section{METHOD}

\section{Samples}

In our study, 50 male patients, who admitted to internet addiction outpatient clinic in Bakirkoy Research and Training Hospital for Psychiatry, Neurology and Neurosurgery were included sequently. Patients were diagnosed with Internet addiction by experienced clinicians according to Young's (1998) criteria. Eligible patients were older than 18 years old, literate, having enough mental capacity to complete self-reported scales. Written informed consent form for participation to the study was provided for every patient Patients under the age of 18 and with comorbid schizophrenia, psychotic disorder or bipolar affective disorder were excluded from the study. Control group of the study consisted of 50 healthymale subjects, whohad similarsocio-demographic characteristics with the patient group and who did not have a psychiatric admission before. Ethics committee approval was provided prior to the initiation of the study.

Our study sample was restricted to male participants because no women applied to our outpatient clinic who had met our study criteria. Therefore, our control group was also confined to male participants. This may be seen as a limitation of our study, but research using communitybased, online, and clinical samples has shown that Internet addiction is more prevalent among males than females. 


\section{Measurements}

Internet Addiction Test (IAT): A 20-item likert-type scale test, was developed by Young (1998) and scored between 1-5 (8). Turkish validation study of this test was conducted by Balta and Horzum (2008.) One of the 20 items in the test was removed from the scale as it was determined to reduce the reliability for Turkish validation study. The internal consistency reliability of Chronbach's alpha is 0.89 (9).

Beck Depression Inventory (BDI): It is a 21-item scale for measuring the emotional, cognitive, somatic and motivational symptoms of depression that was developed by Beck (1961). Each item is scored between 1 and 3 and total score is calculated by the sum of all items (10). Turkish validation study of this test was conducted by Hisli (1988). Cut-off score was considered as 17 in Turkish validity and reliability study. The internal consistency reliability of Chronbach's alpha is 0.80 (11).

Coping Inventory (COPE): A 60-item likert-type scale test with 15 sub-scales, was developed by Carver et al. (1989) and scored between 1-4. COPE problem focused coping strategies include use of instrumental social support, active coping, restraint coping, suppression of competing activities and planning. Emotional focused coping strategies include positive reinterpretation and growth, turning to religion, humor, use of emotional social support, acceptance. Dysfunctional coping strategies include mental disengagement, focus on and venting of emotions, denial, behavioral disengagement, alcohol-drug disengagement subscales (12). Turkish validation study of the scale was conducted by Agargun et al. (1988) $(\alpha=0.79)(13)$.

\section{Statistical Analysis}

The data of this study was analyzed using SPSS 16 for Windows. For evaluation of the data, descriptive study of statistical methods (frequency, percentage, mean, and standard deviation) as well as Kolmogorov-Smirnov test to examine to normally distribution was used. Qualitative data was compared using chi-square test. Independent samples t-test was used for comparison between groups of normally distributed parameter; Mann Whitney U test was used for comparing non-parametric quantitative data. Numeric variables in the tables as mean \pm standard deviation (mean \pm SD) or median (25\%-75\% of corresponding values), categorical variables and the percent of the total number of observations ( $\mathrm{n}-\%)$ are shown using a notation. As depression might affect the coping strategies in order to determine and externalize its influence multi factorial covariance analysis (ANCOVA) were used. Significance at $\mathrm{p}<0.05$ and $\mathrm{p}<0.001$ were evaluated.

\section{RESULTS}

The age of the study group was 20 (18-23), years while it was 22 (18-24) years for the control group. There was no significant difference between the study and the control group according to their age, education, marital status, occupation ( $\mathrm{p}>0.05)$ (Table 1).

Table 1: Comparison of demographic variables between groups ( $\mathrm{n}=100)$

\begin{tabular}{|c|c|c|c|c|}
\hline & $\begin{array}{c}\text { Patient } \\
\text { Median (25\%-75\%) }\end{array}$ & $\begin{array}{c}\text { Control } \\
\text { Median (25\%-75\%) }\end{array}$ & $z / \chi^{2}$ & $\mathbf{p}$ \\
\hline \multirow[t]{2}{*}{${ }^{+}$Age } & $20(18-23)$ & $22(18-24)$ & -0.417 & 0.67 \\
\hline & n (\%) & n (\%) & & \\
\hline \multicolumn{5}{|c|}{ ++ Level of education (years) } \\
\hline $0-8$ & $6(12 \%)$ & $3(6 \%)$ & & 0.72 \\
\hline $8-12$ & $37(74 \%)$ & $38(76 \%)$ & 0.641 & \\
\hline Over 12 & $7(14 \%)$ & $9(18 \%)$ & & \\
\hline Unemployed & $13(26 \%)$ & $6(12 \%)$ & & \\
\hline \multicolumn{5}{|l|}{${ }^{++}$Occupational status } \\
\hline Student & $21(42 \%)$ & $24(48 \%)$ & 1.263 & 0.53 \\
\hline Employee & $16(32 \%)$ & $20(40 \%)$ & & \\
\hline Single & $42(84 \%)$ & $39(78 \%)$ & & \\
\hline \multicolumn{5}{|l|}{${ }^{++}$Marital status } \\
\hline Married & $7(14 \%)$ & $10(20 \%)$ & 3.223 & 0.20 \\
\hline Divorced & $1(2 \%)$ & $1(2 \%)$ & & \\
\hline
\end{tabular}

${ }^{+}$Mann-Whitney $\mathrm{U}$ test, ${ }^{++}$Chi-square test, $\mathrm{p}<0.05$ level of significance 
Table 2: Comparison of duration of internet use, IAT, BDI scores between groups and correlation of IAT and BDI scores ( $\mathrm{n}=100$ )

\begin{tabular}{|c|c|c|c|c|}
\hline & $\begin{array}{c}\text { Patient } \\
\text { Median }(25 \%-75 \%)\end{array}$ & $\begin{array}{c}\text { Control } \\
\text { Median (25\%-75\%) }\end{array}$ & $\mathbf{Z}$ & $\mathbf{p}$ \\
\hline${ }^{+}$Duration of internet use & $8(7-10)$ & $3(1-4)$ & -8.544 & $<0.001$ \\
\hline${ }^{+} \mathrm{IAT}$ & $48(40-63)$ & $24(20-69)$ & -8.225 & $<0.001$ \\
\hline \multirow[t]{3}{*}{ +BDI } & $16.5(8.5-31)$ & $6(2.5-11)$ & -4.755 & $<0.001$ \\
\hline & \multicolumn{4}{|c|}{ BDI } \\
\hline & $\mathbf{r}$ & & $\mathbf{p}$ & \\
\hline${ }^{++}$IAT (patient group) & 0.433 & & 0.002 & \\
\hline${ }^{++}$IAT (control group) & 0.328 & & 0.02 & \\
\hline
\end{tabular}

${ }^{+}$Mann-Whitney U test, + + Spearman correlation test, $\mathrm{p}<0.05$ level of significance, IAT: Internet Addiction Test, BDI: Beck Depression Inventory

Table 3: Comparison of cope scores in patient and control groups $(n=100)$

\begin{tabular}{|c|c|c|c|c|}
\hline COPE & $\begin{array}{c}\text { Patient } \\
\text { Mean } \pm \text { SD }\end{array}$ & $\begin{array}{c}\text { Control } \\
\text { Mean } \pm \text { SD }\end{array}$ & $\mathbf{p}^{+}$ & $\mathbf{p}^{++}$ \\
\hline \multicolumn{5}{|l|}{ PROBLEM FOCUSED } \\
\hline Use of instrumental social support & $9.4 \pm 3.3$ & $11.6 \pm 2.8$ & 0.001 & 0.006 \\
\hline Active coping & $9.6 \pm 2.5$ & $12.4 \pm 2.5$ & $<0.001$ & $<0.001$ \\
\hline Restraint coping & $9.5 \pm 2.2$ & $9.2 \pm 1.9$ & 0.42 & 0.32 \\
\hline Suppression of competing activities & $9.5 \pm 2.7$ & $10 \pm 2.4$ & 0.34 & 0.62 \\
\hline Planning & $9.8 \pm 2.9$ & $12.3 \pm 2.6$ & $<0.001$ & $<0.001$ \\
\hline Total & $47.5 \pm 11.3$ & $55.8 \pm 9.4$ & $<0.001$ & 0.002 \\
\hline \multicolumn{5}{|l|}{ EMOTIONAL FOCUSED } \\
\hline Positive reinterpretation and growth & $10.6 \pm 2.6$ & $13.1 \pm 2.0$ & $<0.001$ & $<0.001$ \\
\hline Turning to religion & $11.2 \pm 4$ & $13.6 \pm 2.3$ & $<0.001$ & 0.003 \\
\hline Humour & $9.4 \pm 3.3$ & $7.9 \pm 2.1$ & 0.008 & 0.05 \\
\hline Use of emotional social support & $9.7 \pm 3$ & $11.2 \pm 2.6$ & 0.001 & 0.01 \\
\hline Acceptance & $8.6 \pm 2.8$ & $9.4 \pm 2.8$ & 0.17 & 0.02 \\
\hline Total & $49.8 \pm 9.9$ & $55.4 \pm 6.7$ & 0.002 & 0.001 \\
\hline \multicolumn{5}{|l|}{ DYSFUNCTIONAL } \\
\hline Mental disengagement & $10.7 \pm 2.4$ & $9.2 \pm 1.9$ & 0.002 & 0.21 \\
\hline Focus on and venting of emotions & $10 \pm 2.7$ & $11.5 \pm 2.4$ & 0.007 & 0.02 \\
\hline Denial & $8 \pm 2.8$ & $6.7 \pm 2.1$ & 0.01 & 0.17 \\
\hline Behavioral disengagement & $7.8 \pm 2.4$ & $5.9 \pm 2.2$ & $<0.001$ & 0.01 \\
\hline Alcohol-drug disengagement & $5.5 \pm 2.8$ & $4.2 \pm 1$ & 0.004 & 0.49 \\
\hline Total & $41.4 \pm 8.4$ & $37.6 \pm 5.9$ & 0.01 & 0.48 \\
\hline
\end{tabular}

$\mathrm{p}^{+}=$Student's-t test, $\mathrm{p}^{++}=$after analysis with ANCOVA, $p<0.05, p<0.001$ level of significance

In study group internet use were specific for 35 patients (70\%) and generalized for 15 patients $(30 \%)$. Distribution of specific internet use was as follows; games: 24 (68.5\%), gambling: 5 (14.2\%), sex: 4 (11.4\%), shopping $2(5.7 \%)$.

The daily duration of internet use was 8 (7-10) hours in the study group while it was $3(1-4)$ hours in the control group. Respectively, the BDI score for the study group was 16.5 (8.5-31) and 6 (2.5-11) in the control group. The IAT score was 48 (40-63) in the study group and 24 (20-29) in the control group. There was a significant difference between the daily duration of internet use, BDI and IAT scores $(\mathrm{p}<0.001)$ (Table 2).

When we compare the study and control group with student t test ; For control group 'active coping', 'planning', 'problem focused total', 'positive reinterpretation and growth', 'turning to religion' scores while for study group 'behavioral disengagement' scores were significantly higher $(\mathrm{p}<0.001)$. For control group 'use of instrumental social support', 'use of emotional social support', 'emotional focused total', 'focus on and venting of emotions' scores and for study group 'humor', 
'mental disengagement', 'denial', 'alcohol-drug disengagement', 'dysfunctional total' scores were significantly higher $(\mathrm{p}<0.05)$. After controlling the mixing effect of depression coping strategies 'humor', 'mental disengagement', 'denial', 'alcohol-drug disengagement', 'dysfunctional total' scores were not significantly different anymore but 'acceptance' scores in control group become significant $(\mathrm{p}<0.05)$ (Table 3$)$.

\section{DISCUSSION}

Dysfunctional coping strategies, especially emotion focused and avoidant coping styles have important role in etiology of psychiatric disorders $(6,14)$. In our study we investigated coping strategies in internet addiction that is assessed as a relatively new clinical disorder. Although, several comorbid psychiatric disorders were co-existing with internet, it was established that internet addiction has the strongest relation with depression (15). Because of that we externalize the influence of depression.

Problem-focused coping strategies are directed to solving or preventing problems. However, emotionfocused coping is used for coping with negative emotions, arising from the problems (16). In our study, total problem-focused coping and use of instrumental social support, active coping component and planning strategies that are problem-focused coping methods were significantly lower in patient group compared with the control group. After controlling the mixing effect of depression there was no significant difference. Patient group was considered as not asking advice, assistance, or information for resolving their problems, and in the presence of a stressor they did not have any attempt or realistic preventions either for solving their problems or reduce the stressor, and they had not develop any action plan to solve their problems (12).

There was no difference between two groups for suppression of competing activities and restraint coping scores. We think that as the study group overuses the internet, they might stay at a distance to other activities and their insufficient daily behavioral repertoire in real life may lead to this result.

Emotional focused coping strategies have been reported as having both positive consequences such as reducing intensive stress and directing patients for using problem focused coping strategies, and some negative consequences such immobilizing the patient and preventing them to take problem focused actions (17). In our study, total emotional focused coping and positive reinterpretation and growth, turning to religion, humor and use of emotional social support from emotional focused coping methods were found to be lower than the control group. After controlling the confounding effect of depression, humor was not significant. The acceptance scores in control group, became significant statistically. Patients were considered as having difficulties for managing the emotional distress that was cued by the situation, and they appealed less to religion for emotional support or positive reinterpretation and growth, and they get less moral support, sympathy or understanding (12). Some of the needs that are met by internet overuse may also be met through religion. So religion may play a protective role for internet addiction (18). Non-depressive people with internet addiction might have humorous point of view for some of their problems.

Dysfunctional coping strategies have been reported to increase the psychological distress as a consequence of negative response of stress and conceptualization of the solution as difficult or impossible (12). In our study, total dysfunctional coping, mental disengagement, denial, behavioral disengagement, alcohol-drug disengagement among dysfunctional coping methods were higher and focus on and venting of emotions were lower than the control group. After controlling the confounding effect of depression coping strategies mental disengagement, denial, alcohol-drug disengagement, dysfunctional total scores were not significantly different anymore.

Internet use is a passive activity so that it is possible to overuse for hours long. It may be called a coping mechanism for the ones who do not work on solving the problem. The people with internet addiction have the tendency for ignoring the problem instead of defining it and may arrange their feelings without using adaptive coping strategies (19).

During a depressive process, rumination response styles were going to change (20). We did not have the sufficient information about the prognosis and the period of depression. Rumination response styles that are related to acceptance, denial and mental disengagement coping differences between two groups may be because of the cross sectional nature of the study. 


\section{Limitations}

There are some limitations to the present study. Due to the absence of female referrals to our Internet Addiction Clinic who met our inclusion criteria, we conducted our study with a sample composed of males. We didn't use scales to diagnose disorders in the patients. We diagnosed internet addiction using our clinical examination. It may be another limitation for our study. Our study includes patients with generalized (chat, e-mail) and specific (games, gambling, etc.) internet addiction who were admitting our clinic. Future studies that evaluate the specific and generalized subtypes independently and establish the possible differences in coping strategies may be helpful. Another limitation of our study is that we did not evaluate the individual differences which might influence the coping strategies (21).

\section{References:}

1. Young KS. Internet Addiction: The emergence of a new clinical disorder. Cyberpsychol Behav. 1998;1:237-44.

2. Şenormancı Ö, Konkan R, Sungur MZ. Internet addiction and its cognitive behavioral therapy. Anatolian Journal of Psychiatry. 2010;11:261-8.

3. American Psychiatric Association. (2013). Diagnostic and statistical manual of mental disorders (fifth ed.). Washington, DC: American Psychiatric Association, 2000

4. Folkman S, Lazarus RS, Gruen RJ, DeLongis A. Appraisal, coping, health status, and psychological symptoms. J Pers Soc Psychol. 1986;50:571-9.

5. Lazarus RS. From psychological stress to the emotions: a history of changing outlooks. Annu Rev Psychol. 1993;44:1-21.

6. Rohde P, Lewinsohn PM, Tilson M, Seeley JR. Dimensionality of coping and its relation to depression. J Pers Soc Psychol. 1990;58:499-511.

7. Hetzel-Riggin MD, Pritchard JR. Predicting problematic Internet use in men and women: the contributions of psychological distress, coping style, and body esteem. Cyberpsychol Behav Soc Netw. 2011;14:519-25.

8. Young KS. Caught in the net: How to recognize the signs of Internet addiction and a winning strategy for recovery, New York: John Wiley; 1998.

9. Balta ÖÇ, Horzum MB. Internet addiction test. Educational Science and Practice. 2008;7:87-102 (in Turkish).

10. Beck AT, Ward CH, Mendelson M, Mock J, Erbaugh J. An inventory for measuring depression. Arch Gen Psychiatry. 1961;4:561-71.

11. Hisli N. Beck A study on the validity of Beck Depression Inventory. Turkish Journal of Psychology. 1988;6:118-26 (in Turkish).

12. Carver CS, Scheier MF, Weintraub JK. Assessing coping strategies: a theoretically based approach. J Pers Soc Psychol. 1989;56:267-83.
Furthermore, it is known that there are differences in coping strategies among cultures (22). Studies involving patients of both genders from other cultures may be helpful.

\section{CONCLUSION}

It can be suggested that patients with internet addiction avoid determining and coping with stressor rather than focusing directly towards source of stress and trying to reduce it. In therapy for internet addiction, defining treatment goals together with the patient and implementing treatment interventions for problem solving may be beneficial. Among people with internet addiction who use maladaptive coping strategies may be at higher risk for relapse. The effect of coping strategies for relapse should be studied by longitudinal researches.

13. Agargun MY, Beşiroglu L, Kıran UK, Özer ÖK, Kara H. The psychometric properties of the COPE inventory in Turkish sample: a preliminary research. Anatolian Journal of Psychiatry. 2005;6:221-6 (in Turkish).

14. Endler N, Parker J. Assessment of multidimensional coping: Task, emotion, and avoidance strategies. Psychol Assess. 1994;6:50-60.

15. Carli V, Durkee T, Wasserman D, Hadlaczky G, Despalins R, Kramarz E, et al. The Association between Pathological Internet Use and Comorbid Psychopathology: A Systematic Review. Psychopathology 2013;46:1-13.

16. Lazarus RS, Folkman S. Stress Appraisal, and Coping, New York: Springer Publishing; 1984.

17. Folkman S, Lazarus RS. If it changes, it must be a process: study of emotion and coping during three stages of a college examination. J Pers Soc Psychol. 1985;48:150-70.

18. Britton PC. The relation of coping strategies to alcohol consumption and alcohol-related consequences in a college sample. Addict Res Theory. 2004;12:103-14.

19. Cooper ML. Motivations for alcohol use among adolescents: Development and validation of a four-factor model. Psychol Assess. 1994;6:117-28.

20. Treynor W, Gonzalez R, Nolen-Hoeksema S. Rumination reconsidered: a psychometric analysis. Cognit Ther Res. 2003;27:247-59.

21. Merrill JE, Thomas SE. Interactions between adaptive coping and drinking to cope in predicting naturalistic drinking and drinking following a lab-based psychosocial stressor. Addict Behav. 2013;38:1672-8.

22. Folkman S, Lazarus RS, Dunkel-Schetter C, DeLongis A, Gruen RJ. Dynamics of a stressful encounter: cognitive appraisal, coping, and encounter outcomes. J Pers Soc Psychol. 1986;50:992-1003. 